\title{
ANALEMMA AND THE BEGINNING OF MAGHRIB PRAYER ALTERATION (Correlation Of Analemma's Position Towards The Beginning Of Maghrib Prayer According To Ephemeris Calculation)
}

M. Ihtirozun $\mathcal{N i}^{\prime}{ }^{\prime}{ }^{1}$, Khabi6 Suraya ${ }^{2}$

${ }^{1}$ Walisongo State Islamic University of Semarang, ${ }^{2}$ Institute for Sains and Religion Study

${ }^{1}$ ihtirozun_n@walisongo.ac.id, ${ }^{2}$ khabibsuraya@gmail.com

\section{Abstract :}

Analemmaa is a change of sun's position which is inconstant when it is observed in certain time and place during a year period. If the change is served as a diagram, it will shape like 'eight' number. The beginning of maghrib prayer during a year period is dyanmic at certain time, and it will change due to alteration of sunset. Therefore, this research aimed to understand the correlation between analemma and the alteration of maghrib prayer schedule. The research uses field research method, which collecting the average of observation data of Sun's position at the certain time and place during a year period by employing qualitative method. The research found that the alteration of the beginning of maghrib prayer is caused by the analemma's phenomenon. When the gap between the result of analema's time observed with maghrib schedule is increased, so the beginning of maghrib prayer is delayed. Yet, when the gap between the result of analema's time observed with maghrib schedule is decreased, so the beginning of maghrib prayer is sooner.

Keywords : Analemma, Maghrib Prayer Time, Inconstant of Maghrib Prayer Time

Abstrak :

Analemmaa merupakan perubahan posisi matahari yang tidak tetap saat diamati pada waktu dan tempat yang sama dalam rentang waktu satu tahun, perubahan ini jika disajikan dalam bentuk diagram akan membentuk seperti angka delapan. Awal waktu shalat maghrib dalam rentang waktu satu tahun tidak statis pada waktu tertentu, tetapi mengalami perubahan dikarenakan waktu terbenamnya matahari mengalami perubahan. Oleh karena itu, penelitian ini bertujuan untuk mengetahui korelasi antara analemma dan perubahan awal waktu shalat maghrib. Penelitian ini menggunakan metode field research yaitu penulis mengumpulkan data rata-rata observasi posisi matahari pada waktu dan tempat yang sama dalam rentang 
waktu satu tahun dengan menggunakan pendekatan kuantitatif. Dari penelitian yang telah dilakukan diketahui bahwa penyebab dari perubahan awal waktu shalat maghrib disebabkan oleh fenomena analemma, dimana ketika nilai selisih waktu bidik citra analemma dengan waktu maghrib bertambah maka awal waktu shalat maghrib melambat dan ketika nilai selisih waktu bidik citra analemma dengan waktu maghrib berkurang maka awal waktu shalat maghrib semakin cepat.

Kata Kunci : Analemma, Waktu Shalat Maghrib, Maju Mundurnya Waktu Shalat Maghrib

\section{A. Introduction}

The beginning of praying or sholat time is an urgent aspect for Moslem. Because, according to Syafi'iyah scholars, understanding the beginning of praying time is one of the requirement in doing Sholat, meaning that Moslem are not allowed to Sholat before the schedule is begins. ${ }^{1}$ Besides its urgency in Sholat, the beginning of sholat especially maghrib, is also important during Ramadhan month. This is because according to sharia, Moslem's fasting started from Fajr until maghrib, they are forbiden to breakfasting before maghrib or sunset. ${ }^{2}$

In fact, the beginning of maghrib praying experiences inconstant in each regional time unit. This inscontant occurred at the early minutes of the beginning maghrib hour which caused by different sunset time in each day. Then this phenomenon make some people think that maghrib schedule is always inconstant, so they said that it sometimes earlier or later.

When we look from the parameters of the Sunset as a sign of the start of praying time, so, understanding the position of the Sun is also necessary to understand the changes in the beginning of the maghrib praying time. The position of the Sun when it is observed at the same hour and place in the range of one year period, it will shown that the Sun observed from the Earth has inconstant position. This phenomenon will form a diagram like the 'eight' number called analemma.

There are some previous works which scrutinize analemma. Alejandro Gangui 'On times and shadows: the observational analemma', explains that making analemma

\footnotetext{
${ }^{1}$ Syaikh Abdurrahman Al-Juzairi, Fikih Empat Madzhab Jilid 1, vol. 1 (Jakarta: Pustaka Al-Kautsar, 2015), 294.

${ }^{2}$ Muhammad Bin Qasim Al Ghazi, Fathul Qarib AL-Mujib (Semarang: Toha Putra, 2010), 25.
} 
diagrams can be done by observing the position of the shadow when the sun is on the meridian using a gnomon stick. ${ }^{3}$ Then F. Mumtahana et, al. on their research tittled 'Tutulemma of near Equator Partial Solar Eclipse 2016' observed and captured the phenomenon of the Sun every 7.21 a.m on the rooftop of LAPAN Building in Bandung and create the first analemma image in Indonesia containing images of the solar eclipse in $2016 .^{4}$

Furthermore related to praying times, there are several previous studies. Encep Abdul Rojak, et.al., under the title 'Correction of the Altitude of Place toward Fiqh of Praying Times: Analysis of the Praying Schedule in Bandung'. The research explains that Bandung has different plains, thus it affect to the beginning of the Maghrib praying time. Meanwhile, the difference of the height of the city location does not affect the start of the other praying times. ${ }^{5}$ Muhammad Hidayat, entitled 'The Causes of Differences in the Calculation Results of Praying Times in North Sumatra'. This work found that the difference results of the calculation of praying schedule is caused by some of the data used between one calculation and another are different. Besides, the time correction of the area does not use as the calculated location but uses another location. ${ }^{6}$ Ismail researched 'The Method in Determining the Beginning of Praying Times in the Perspective of Falak Science', explained that the data on the height of the place affects the calculation results of the beginning maghrib, isya, and subuh praying times. Meanwhile the brightness of the sky it affects the calculation results of the beginning of Isha and subuh praying times. ${ }^{?}$

According to these background and previous researchs, the presence of the analemma phenomenon and the change in the beginning of the maghrib prayer time,

\footnotetext{
3 Alejandro Gangui, Cecilia Lastra, and Fernando Karaseur, "On Times and Shadows: The Observational Analemma," The Physics Teacher, 2018.

${ }^{4}$ F. Mumtahana et al., "Tutulemma of near Equator Partial Solar Eclipse 2016," Journal of Physics: Conference Series 771, no. 1 (2016).

${ }^{5}$ Encep Abdul Rojak, Amrullah Hayatudin, and Muhammad Yunus, "Koreksi Ketinggian Tempat Terhadap Fikih Waktu Salat: Analisis Jadwal Waktu Sholat Kota Bandung,” Al-Ahkam, 2017.

${ }^{6}$ Muhammad Hidayat, "Penyebab Perbedaan Hasil Perhitungan Jadwal Waktu Salat Di Sumatera Utara,” Al-Marshad: Jurnal Astronomi Islam Dan Ilmu-Ilmu Berkaitan, 2018.

7 Ismail, "Metode Penentuan Awal Waktu Salat Dalam Perspektif Ilmu Falak," Jurnal Ilmiah Islam Futura, 2015.
} 
the writer interested to scrutinize whether there is a correlation between the analemma phenomenon and the change in the beginning of the maghrib praying time. Therefore, it can be seen whether the analemma phenomenon is one of the causes of the inconstancy of maghrib praying time.

\section{B. Research Method}

Author will employ Field Research for this research. The data will be collected of the position of the Sun at the same hour and position which is carried out for one year by using quantitative approach. This study uses primary sources, namely the data from the observations and the results of the initial calculation of the maghrib praying time based on the ephemeris which is adjusted to the date of analemma data collection. Then author will analyze whether the back and forth of the maghrib praying time is related to the analemma phenomenon or not.

\section{Discussion and Results}

C.1. The Motion of the Celestial Bodies and the Formation of Analemma

The discussion about the movement of celestial bodies has been going on for 2000 years, starting from the classical theory which states that the Earth is the center of the universe which is stated by Aristoteles ${ }^{8}$ and Ptolemy in his book 'Almagest' which states the same thing as Aristotle's argument that the Earth is the center of the Universe. ${ }^{9}$ Then the theory about the center of the universe has developed which previously stated that the Earth was the center of the universe to be the Sun which was actually the center of the universe as stated by Aristarchus. He argued that when the Earth moved around the Sun it would be easy to explain the movement of celestial objects. $^{10}$

The motion of celestial bodies around other celestial bodies is called revolutionary motion, as is done by the earth, planets, and other celestial objects. They

\footnotetext{
${ }^{8}$ Thoha Firdaus and Arini Rosa Sinensis, "Perdebatan Paradigma Teori Revolusi: Matahari Atau Bumi Sebagai Pusat Tata Surya ?," Titian Ilmu: Jurnal Ilmiah Multi Sciences 9 (2017): 23.

9 Nabil, "Pendidikan Ilmu Astronomi Dari Historis Sampai Heliosentris," Al Marhalah: Jurnal Pendidikan Islam 2 (2018): 96.

${ }^{10}$ Nabil, 97.
} 
move around the Sun, because the Sun is the center of the Solar System. ${ }^{11}$ The duration of Earth's revolution around the Sun is called a sidereal year which takes 365 days 5 hours 48 minutes 46 seconds. ${ }^{12}$ In carrying out a revolutionary motion toward the Sun, the Earth and other planets move through an elliptical orbit. ${ }^{13}$ From an elliptical trajectory in one revolution, the Earth will reach the closest distance or called perihelium and the farthest distance is called aphelium. ${ }^{14}$ Besides moving around the sun, the Earth also performs rotational motion, namely the motion of celestial bodies rotating on their axis, ${ }^{15}$ in carrying out its rotational motion, the earth rotates obliquely to its axis of rotation by 23 degrees 27 minutes. ${ }^{16}$

Based on the elliptical-shaped trajectory of the Earth's revolution and its tilt to the axis of rotation of 23 degrees 27 minutes, this causes a phenomenon called analemma, analemma is the position of the Sun on its trajectory as seen from the Earth for one year at the same time and location. ${ }^{17}$ The Sun's position when it combined in one diagram will form a pattern resembling the number $8 .{ }^{18}$ Analemma functioned to determine the location with three coordinate variables, namely the sun's declination, latitude, and hour. ${ }^{19}$

${ }^{11}$ Firdaus and Sinensis, "Perdebatan Paradigma Teori Revolusi: Matahari Atau Bumi Sebagai Pusat Tata Surya ?," 24.

12 Slamet Hambali, "Pengantar Ilmu Falak, Menyimak Proses Pembentukan Alam Semesta," Banyuwangi: Bismillah Publisher, 2012, 132. $2005,39$.

${ }^{13}$ Robbin Kerrod, "Bengkel Ilmu Astronomi, Terj," Syamaun Peusangan, Jakarta: Penerbit Erlangga,

${ }^{14}$ Hambali, "Pengantar Ilmu Falak, Menyimak Proses Pembentukan Alam Semesta," 131.

${ }^{15}$ Muhyiddin Khazin, Kamus Ilmu Falak (Yogyakarta: Buana Pustaka, 2005), 69.

${ }^{16}$ Hambali, "Pengantar Ilmu Falak, Menyimak Proses Pembentukan Alam Semesta," 131.

${ }^{17}$ Mumtahana et al., "Tutulemma of near Equator Partial Solar Eclipse 2016," 1.

${ }^{18}$ Richard A Matzner, Dictionary of Geophysics, Astrophysics, and Astronomy (CRC Press, 2018), 16.

${ }^{19}$ Nathan Sidoli, "Mathematical Methods in Ptolemy's Analemma," in Ptolemy's Science of the Stars in the Middle Ages (Brepols Publishers, 2020), 35. 


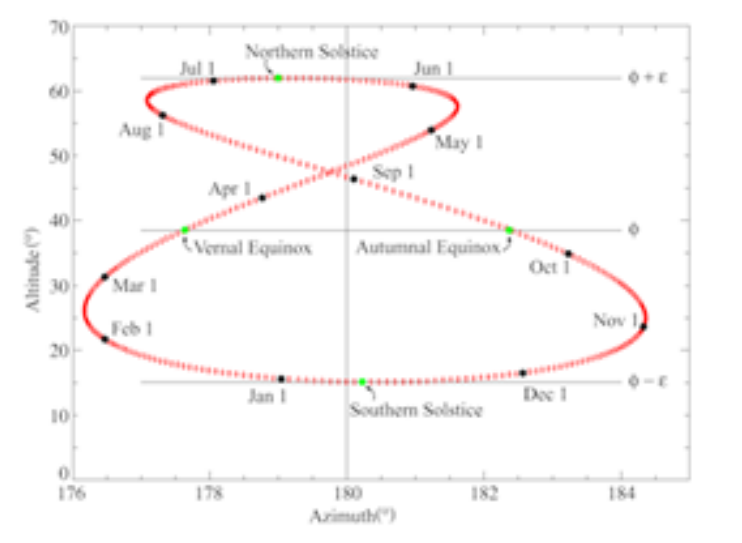

Image 1. Analemma diagram which resemble to 8 number's pattern. ${ }^{20}$

Analemma can be known by observing the sun's shadow at the same time and place in the span of one year using a sundial. ${ }^{21}$ Besides observing the shadows of objects produced by the sun, analemma can also be known by photographing the sun at the same time and place in the span of a year. Dennis di Cicco was the first person to capture the analemma phenomenon with photographic techniques from 27 February 1978 to 17 February 1978 in New England. ${ }^{22}$

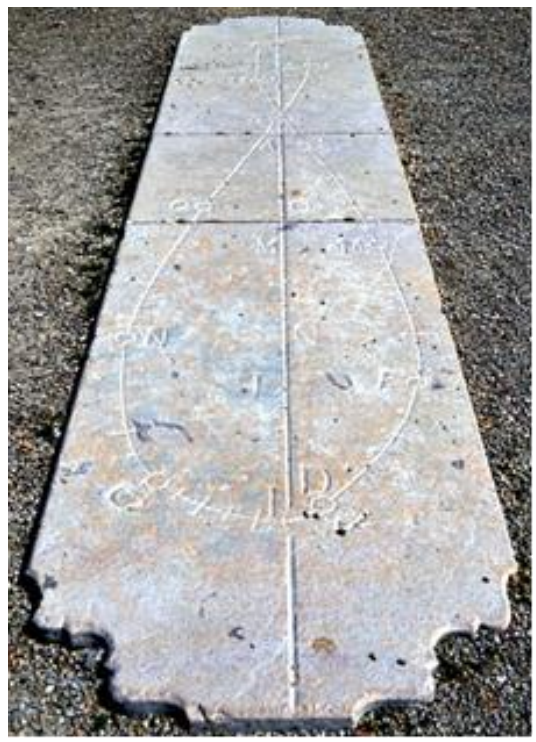

Image 2. Finding analemma phenomenon by using Sundial. ${ }^{23}$

20 The HORIZONZ, “Analemma for Planet Earth," accessed November 11, 2020, https://commons.wikimedia.org/wiki/File:Analemma_Earth.png.

21 Helmer Aslaksen, "The Analemma for Latitudinally-Challenged People The Analemma for Latitudinally-Challenged People Department of Mathematics,” no. January 2001 (2014): 26.

${ }_{22}^{2}$ Mumtahana et al., "Tutulemma of near Equator Partial Solar Eclipse 2016," 1.

23 François Blateyron, "The Analemmatic Sundial," accessed November 11, 2020, https://www.shadowspro.com/en/analemmatic-sundial.html. 


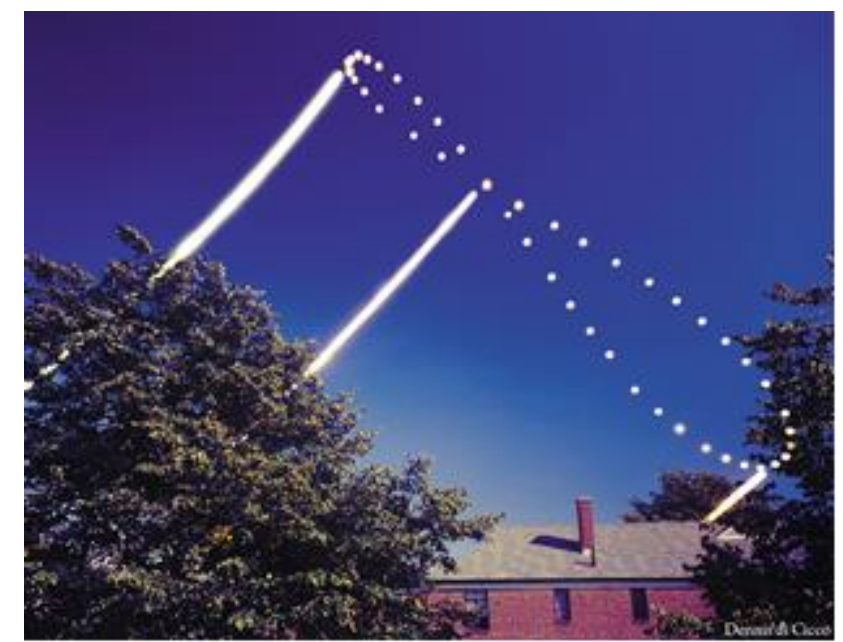

Image 3. The first capture of analemma phenomenon by Dennis in Cicco. ${ }^{24}$

\section{C.2. Maghrib Praying Time According to Fiqh and Astronomy Perspective}

Etymologically, shalat is rooted from the words shala, yashilu, shalatan, which means praying. ${ }^{25}$ Whereas in terminologically sholat is a series of worship in which it contains words and deeds that begin with takbiratul ihram and end with salam. ${ }^{26}$

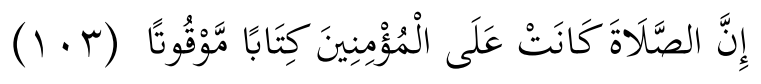

"In fact, praying is a time-determined obligation for those who believe." (QS. An-Nisa' $[4]: 103)^{27}$

According to Tafsir Al - Misbah it is explained that the word mauqutan comes from the word waqt which in language means the deadline for completing a job, in prayer each prayer has its own time where the prayer must be done in time. ${ }^{28}$

Whereas in the interpretation of al Qurtubi, it explains that the meaning of mauqutan has a clear meaning of time, which it has been determined. Then in the interpretation of Ibn Abbas, he explains that the meaning of mauquutan is mafruudhaa,

24 Dennis di Cicco, "The First Ever Analemma," accessed November 11, 2020, http://twanight.org/newTWAN/photos.asp?ID=3001422.

${ }^{25}$ Ahmad Izzuddin, Ilmu Falak Praktis: Metode Hisab-Rukyat: Praktis Dan Solusi Permasalahannya (Pustaka Rizki Putra, 2012), 77.

${ }^{26}$ Slamet Hambali, "Ilmu Falak I (Penentuan Awal Waktu Salat Dan Arah Kiblat Dunia)," Semarang: Program Pasca Sarjana IAIN Walisongo Semarang, 2011, 107.

${ }^{27}$ R I Kemenag, “Al-Qur’an Dan Terjemahnya,” Jakarta: PT Sinergi Pustaka Indonesia, 2012, 134.

${ }^{28}$ Zulfia Aviv, "Studi Analisis Ihtiyath 10 Menit Sebelum Subuh Untuk Waktu Imsak Dalam Sistem Informasi Hisab Rukyat (Sihat) Indonesia” (Universitas Islam Negeri Walisongo Semarang, 2017), 18. 
which is something that is required. ${ }^{29}$ This chapter becomes the argument for praying times, there are two opinions regarding the sentence "kitaban mauquta", the first opinion defines as an obligation without accompanying time, then the second opinion interprets the sentence "kitaban mauquta" as the specified time. ${ }^{30}$ The second opinion is the valid one. The praying ritual is also called muwaqqat worship, because the praying ritual has a predetermined time even though it is not explained textually in the AlQur'an but it has been regulated by syar'i / Islamic law. ${ }^{31}$

Imam Asy-Syafi'I stated in Al Umm that maghrib prayer starts at sunset. ${ }^{32}$ The indicator of the Sunset is that all parts of the Sun's disc are invisible to sight. ${ }^{33}$ In the opinion of the scholars' Shafi'iyyah, to know the perfect sunset can be seen when observed in the desert, then for urban areas and in the mountains the indicator for perfect sunset is when there is no sunlight on the walls and hills, then in the east it starts to get dark. ${ }^{34}$ Furthermore, the Shi'ah group argue that the beginning of the maghrib praying time begins when the stars in the sky are clearly visible. ${ }^{35}$ From these opinions, it is actually the same as the agreement of scholars' regarding maghrib time starting at sunset totally.

Historically, astronomical determination of the beginning of praying time has been started since the time of the Prophet Muhammad with the existence of hadiths about the Jibril who met and taught the Prophet about the beginning of praying time where the indicator of the time is the position of the Sun. ${ }^{36}$ The beginning of the maghrib praying time is astronomically formulated when the disk of the Sun touches the horizon or $u f u k$, this event is called the Sunset. ${ }^{37}$ The position of the Sun during

${ }^{29}$ Ali bin Abi Thalhah, "Tafsir Ibnu Abbas," Jakarta: Pustaka Azzam, 2009, 214.

${ }^{30}$ Hambali, "Ilmu Falak I (Penentuan Awal Waktu Salat Dan Arah Kiblat Dunia)," 107.

${ }^{31}$ Fathul Ulum, "Studi Komparatif Hisab Penentuan Awal Waktu Shalat Dalam Kitab Al-Durusul AlFalakiyah Dan Ephemeris” (Institut Agama Islam Negeri Ponorogo, 2020), 145.

${ }^{32}$ Asy Syafi' 'i, Al Umm Jilid 2 Terj. Misbah (Jakarta: Pustaka Azzam, 2014), 36.

${ }_{33}$ Al-Juzairi, Fikih Empat Madzhab Jilid 1, 1:304; An-Nawawi, Al-Majmu' Syarah Al-Muhadzdzab Jilid 3 (Jakarta: Pustaka Azzam, 2015), 69.

${ }^{34}$ An-Nawawi, Al-Majmu' Syarah Al-Muhadzdzab Jilid 3, 70.

${ }^{35}$ An-Nawawi, 76.

${ }^{36}$ Haliah Ma'u, Dahliah, "Waktu Sholat Pemaknaan Syar' I Ke Dalam Kaidah Astronomi," Jurnal Hukum Islam 14, no. 2 (2015): 270.

${ }^{37}$ Muhajir, “Awal Waktu Shalat Telaah Fiqh Dan Sains,” Madinah: Jurnal Studi Islam 6 (2019): 45-46. 
sunset is astronomically defined when the zenith distance is 90 degrees 50 minutes, this 50 minute value is generated from the sum of the semi-diameter of the Sun which is 16 minutes with a value of refraction of 34 minutes. ${ }^{38}$ In addition, the zenith distance is also defined as 91 degrees when adding the observer's height correction value of 30 meters above sea level. ${ }^{39}$ The distance measured from the Sun's position to the zenith point is a definition of the zenith distance. ${ }^{40}$ Ufuk or in astronomical terms called as horizon is a circle that divides the sky as large as that which can be seen by the observer and that which cannot be seen. It can also be called as a sky divider. ${ }^{41}$

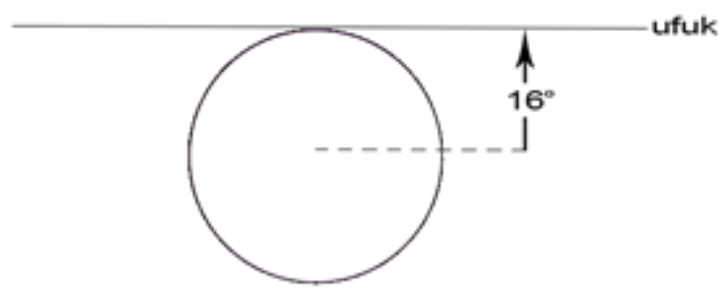

Image 4. The sunset is when the entire sun is below the horizon and the edge of the sun's disk touches the horizon

Some aspects related to the beginning of the maghrib time include refraction. Refraction is the difference in the height of the position of a celestial body which can be seen with its actual position due to the process of refraction of the rays. ${ }^{42}$ The difference in the distance between each layer of the atmosphere is the cause of the refraction of the rays emitted by a celestial body. So, the visible object that is visible to the observer's view is higher than the actual height. ${ }^{43}$ Regarding to the use of refraction correction in the initial calculation of maghrib time, there are two opinions. The first opinion of some astronomers states that this refraction correction should be used in all locations. Then the second opinion states that refraction correction is only used in certain locations. ${ }^{44}$ Then the aspect that affects the beginning of the maghrib time is the height of the place,

38 Abu Sabda, Ilmu Falak Rumusan Syar'i Dan Astronomi Seri 01: Waktu Shalat Dan Arah Kiblat (Bandung: Persis Pers, 2020), 59. 43.

39 Arwin Juli Rakhmadi Butar-Butar, "Pengantar Ilmu Falak," Cet. I, Yogyakarta: Rajawali Pers, 2018,

\footnotetext{
${ }^{40}$ Hambali, "Ilmu Falak I (Penentuan Awal Waktu Salat Dan Arah Kiblat Dunia)," 56.

${ }^{41}$ Susiknan Azhari, Ensiklopedi Hisab Rukyat (Yogyakarta: Pustaka Pelajar, 2012), 223.

${ }^{42}$ Khazin, Kamus Ilmu Falak, 19.

${ }^{43}$ Azhari, Ensiklopedi Hisab Rukyat, 180.

${ }^{44}$ Sabda, Ilmu Falak Rumusan Syar'i Dan Astronomi Seri 01 : Waktu Shalat Dan Arah Kiblat, 61.
} 
because someone who is in a high place will see the sun set longer than people who are in a lower location.

C.3. The Calculation of Maghrib Praying Time According to the Ephemeris System.

Ephemeris is a book or a collection of tables containing data on the location of celestial bodies, whether they are planets or satellites. ${ }^{45}$ The Ministry of Religion of the Republic of Indonesia publishes the book Ephemeris Hisab Rukyat every year, this book provides astronomical data of the Sun and moon for various purposes of hisab / calculation. ${ }^{46}$ In the following calculations we will discuss about the calculation of the beginning of the maghrib praying time using the initial calculation of the ephemeris system. The ephemeris system is a calculation using astronomical data from the book Ephemeris Hisab Rukyat.

In calculating the beginning of maghrib praying schedule, some data are needed, as following: ${ }^{47}$

1. The latitude of the place $(\phi)$

The latitude of a place is the distance measured from a place to the equator along the earth's meridian. ${ }^{48}$

2. The longitude of the place $(\lambda)$

The longitude of a place is the measured distance from Greenwich city to a place along the Earth's equatorial arc. ${ }^{49}$

3. Equation of time (e )

Equation of time is the time difference between the middle sun and the real time of Sun's angle. ${ }^{50}$

4. Sun's Declination $\left(\delta_{0}\right)$

\footnotetext{
${ }^{45}$ Matzner, Dictionary of Geophysics, Astrophysics, and Astronomy, 156.

${ }^{46}$ Azhari, Ensiklopedi Hisab Rukyat, 62.

47 Kemenag RI, Ilmu Falak Praktik (Jakarta Pusat: Sub Direktorat Pembinaan Syariah Dan Hisab

${ }^{48}$ Azhari, Ensiklopedi Hisab Rukyat, 134.

49 Azhari, 47.

${ }^{50}$ Departemen Agama RI, Ephemeris Hisab Rukyat 2021 (Jakarta: Direktorat Urusan Agama Islam,
} Rukyat, 2013), 86. 2021), 2. 
The declination of the Sun is the distance between the Sun and the equator calculated along the circle of declination. ${ }^{51}$

5. Height of Place

The height of the place is calculated from sea level to the height of a place. The height of this place is used to determine the level of the horizon. ${ }^{52}$

In calculating the beginning of maghrib praying schedule, the first step that must be taken is to collect data. The data is the latitude and longitude of the place, which can be found in several appendices for books that discuss astronomy or from other sources. Then we have to find the data about height of place, this data can be obtained via GPS or from other sources.

Meanwhile related to data of the Sun which used for the purpose of this calculation, it retrieved from the book Ephemeris Hisab Rukyat of the Ministry of Religion of the Republic of Indonesia. The data provided in the book is Universal Time data or the Greenwich Mean Time, so if the calculation location is in another place then you have to adjust the time. For the initial calculation of maghrib time, it is assumed that the maghrib time is 6 p.m., so the data taken in the Ephemeris Hisab Rukyat book of the Ministry of Religion is 6 p.m. minus 7 hours (the difference between Greenwich and WIB). The first data taken is the declination of the sun and the equation of time at 11 o'clock. $^{53}$

After the data has been collected, the first step to calculate the beginning of the maghrib time of the ephemeris system is to calculate the horizon, with the formula:

$$
0^{\circ} 1.76^{\prime} \times \sqrt{\text { height }}
$$

After we found the horizon's level, then height of the Sun can be calculated with the following formula:

$h_{0}=-(r e f+S D+K U)$ the average value of refraction; $0^{\circ} 34$ ' 0 '. Then $\mathrm{SD}$ is the semidiameter of the sun, the value used also uses the average of the Sun diameter; $0^{\circ}$

\footnotetext{
${ }^{51}$ Khazin, Kamus Ilmu Falak, 51.

${ }^{52}$ RI, Ilmu Falak Praktik, 86.

${ }^{53}$ RI, 86.
} 
16 ' 0 '. Then $\mathrm{KU}$ is the level of horizon that has been calculated in the previous calculation.

The next step is to calculate the time angle of the Sun with the formula:

Cos to $=\operatorname{Sin} h_{o}: \operatorname{Cos} \phi: \operatorname{Cos} \delta_{o}-\operatorname{Tan} \phi \times \operatorname{Tan} \delta_{o}$

ho signs for the sun's height data that has been obtained in previous calculations. Then the data $\varphi$ is the latitude of the place, it can be found in several Astronomic refferences. Then $\delta o$ data is the declination of the sun, which is retrieved from the ephemeris data in the Ephemeris Hisab Rukyat book of the Ministry of Religion of the Republic of Indonesia.

After getting the sun's time angle in degrees format, then the results are converted into "hours-minutes seconds" by using the following pattern:

The time angle / 15

From the above calculation, it results a time angle in hour format which will be used to calculate the start of the maghrib praying time.

The next step is to calculate the beginning of maghrib time with the formula:

$$
\text { Maghrib praying time }=(12+\text { to })-\mathrm{e}+((\mathrm{BD}-\lambda): 15)
$$

The data to is the solar time angle that has been calculated in the previous calculation in hourly format. Then data e is the equation of time taken from the Ephemeris Hisab Rukyat book of the Ministry of Religion of the Republic of Indonesia. Then BD is Regional Longitude, namely the division of time in Indonesia which is divided into three time divisions with each time having a longitude differences of $15^{\circ}$, namely WIB (West Indonesian Time) with a value of $105^{\circ}$, then WITA (Central Indonesian Time) with a value of $120^{\circ}$, and lastly is WIT (Eastern Indonesian Time) with a value of 135 ${ }^{\circ 54}$ Then the $\lambda$ data is the longitude data of the place, it can be retrieved by GPS or astronomy books.

54 Slamet Hambali, "Menguji Kakuratan Hasil Pengukuran Arah Kiblat Menggunakan Istiwaaini Karya Slamet Hambali,” 2014, 40. 
After the results beginning of maghrib time has been obtained. The final step is to add the results with ihtiyat. Ihtiyat is a step for security purposes so that the praying and fasting times which are calculated according to their respective time do not precede the beginning of time or exceed the end of time. ${ }^{55}$ The reason for adding ihtiyat in the initial calculation of prayer times is due to rounding and simplification in the data collection process. ${ }^{56}$ Moreover, ihtiyat is important to determine the location in the form of latitude and longitude which is usually centered on one point. Meanwhile the results of the initial calculation of praying times are usually used in a wide range of the radius of the center of latitude and longitude, therefore to distribute the time to a location that far from the center city we have to add or subtract ihtiyat. ${ }^{57}$ This ihtiyat in the calculation is sometimes added or subtracted. The time of imsak and subuh is subtracted. Meanwhile, it is added by 1 to 2 minutes for the others praying schedule. ${ }^{58}$

The following is an example of calculating the beginning of maghrib time using the ephemeris system:

\begin{tabular}{|c|c|}
\hline City & $=$ Pasuruan \\
\hline Date & $=19$ September 2020 \\
\hline$\phi$ & $=-7^{\circ} 40^{\prime} \mathrm{LS}$ \\
\hline$\lambda$ & $=112^{\circ} 55^{\prime} \mathrm{BT}$ \\
\hline e & $=0^{\circ} 6^{\prime} 21^{\prime \prime}$ \\
\hline$\delta_{o}$ & $=1^{\circ} 12^{\prime} 27^{\prime \prime}$ \\
\hline TT & $=15 \mathrm{Mdpl}$ \\
\hline SD & $=0^{\circ} 16^{\prime} 0^{\prime \prime}$ \\
\hline Ref & $=0^{\circ} 34^{\prime} 0^{\prime \prime}$ \\
\hline \multirow[t]{3}{*}{ DIP } & $=0^{\circ} 1.76^{\prime} \times \sqrt{\text { height }}$ \\
\hline & $=0^{\circ} 1.76^{\prime} \times \sqrt{ } 15$ \\
\hline & $=0^{\circ} 6^{\prime} 49^{\prime \prime}$ \\
\hline ho & $=-(\mathrm{ref}+\mathrm{SD}+\mathrm{DIP})$ \\
\hline
\end{tabular}

\footnotetext{
${ }^{55}$ Khazin, Kamus Ilmu Falak, 33.

${ }^{56}$ Azhari, Ensiklopedi Hisab Rukyat, 92.

${ }^{57}$ Azhari, 92.

${ }^{58}$ Muhyiddin Khazin, Ilmu Falak Dalam Teori Dan Praktik (Yogyakarta: Buana Pustaka, 2005), 95.
} 


$$
\begin{aligned}
& =-\left(0^{\circ} 34^{\prime} 0^{\prime \prime}+0^{\circ} 16^{\prime} 0^{\prime \prime}+0^{\circ} 6^{\prime} 49^{\prime \prime}\right) \\
& =-0^{\circ} 56^{\prime} 49^{\prime \prime}
\end{aligned}
$$

Cos to $\quad=$ Sin ho $: \operatorname{Cos} \phi: \operatorname{Cos} \delta_{o}-\operatorname{Tan} \phi \times \operatorname{Tan} \delta_{o}$

$=\operatorname{Sin} 0^{\circ} 56^{\prime} 49^{\prime \prime}: \operatorname{Cos}-7^{\circ} 40^{\prime}: \operatorname{Cos} 1^{\circ} 12^{\prime} 27^{\prime \prime}-\operatorname{Tan}-7^{\circ} 40^{\prime} \mathrm{x} \operatorname{Tan} 1^{\circ}$

$12^{\prime} 27^{\prime \prime}$

$=90^{\circ} 47^{\prime} 35.18^{\prime \prime}$

to

$=90^{\circ} 47^{\prime} 35.18^{\prime \prime}: 15$

$=6 \mathrm{j} 3 \mathrm{~m} 10.35 \mathrm{~d}$

Maghrib time $=(12+$ to $)-\mathrm{e}+((\mathrm{BD}-\lambda): 15)$

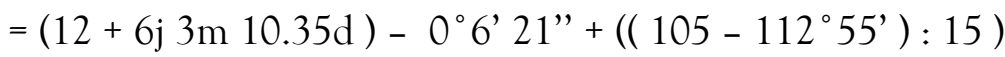

$=17: 25+0 j 2 \mathrm{~m}$ (ihtiyat)

$=17: 27$

Therefore, the beginning of the maghrib praying time for the Pasuruan region on September 19, 2020 based on the ephemeris calculation system is 17:27 WIB.

C.4. Correlation between the Value Changes of the Sun's Declination and the Change of the Beginning of the Maghrib Praying Time

Declination is the distance of a celestial body calculated from the equatorial plane to the celestial body. ${ }^{59}$ The declination is one of the axes in the equatorial coordinate system, the declination will be positive when a celestial body is located north of the equatorial plane $\left(0^{\circ}\right.$ to 909 and negative if a celestial body is south of the equatorial plane $\left(0^{\circ}\right.$ to $-909 .{ }^{60}$ The value of the sun's declination varies with the highest value of 23.5 degrees and the lowest value of -23.5 degrees, ${ }^{61}$ the declination of the sun is due to the earth's rotation with a tilt of 23 degrees 27 minutes. ${ }^{62}$ 2018), 15.

${ }^{59}$ A. Jamil, Ilmu Falak Teori $\mathcal{E}$ Aplikasi (Arah Kiblat, Awal Waktu, Dan Awal Tahun) (Jakarta: AMZAH,

${ }^{60}$ Kerrod, "Bengkel Ilmu Astronomi, Terj," 65.

${ }^{61}$ T Shivalingaswamy and B A Kagali, "Determination of the Declination of the Sun on a Given Day" 3, no. 1 (2012): 17 .

${ }^{62}$ Hambali, "Pengantar Ilmu Falak, Menyimak Proses Pembentukan Alam Semesta," 131. 


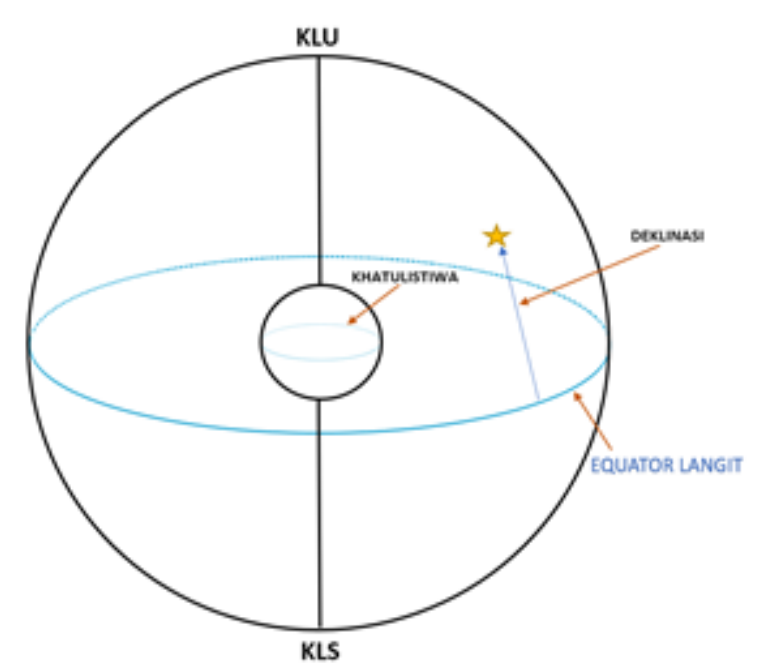

Image 5. The Illustration of Equator Coordinate

From the illustration above, the position of the Sun when its annual journey towards the north pole of the sky will be positive and if it is pointing towards the south pole of the sky, the declination will be negative.

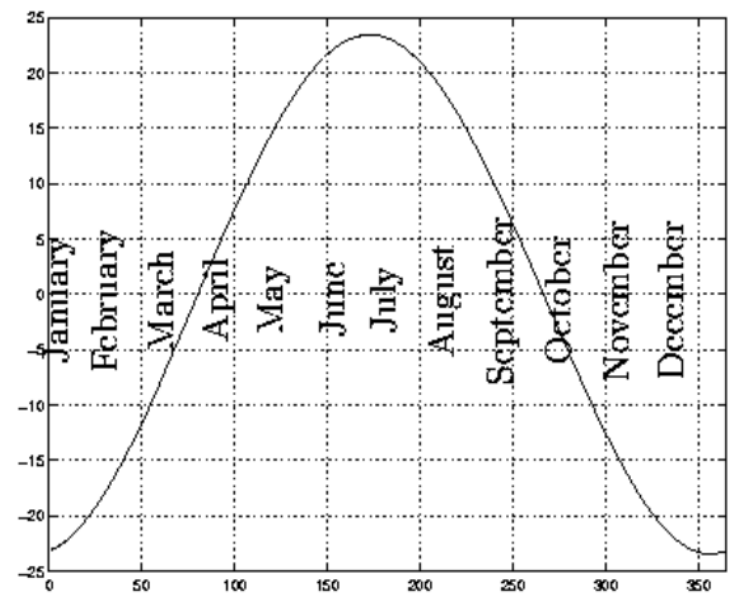

Image 6. Diagram deklinasi matahari dalam satu tahun. ${ }^{63}$

From this diagram we can observe the movement of the sun's declination with a value of $0^{\circ}$ on 21 March and 23 September, the sun's journey after 21 March is to the North until its farthest position is $23^{\circ} 27^{\prime}$ then back towards the south until 23 September is $0^{\circ}$, then continue the journey to the South until its farthest position on 22 December at $-23^{\circ} 26^{\prime}$ then back to the North. ${ }^{64}$

${ }^{63}$ C.J. Budd, "The Declination of The Sun," accessed November 26, 2020, http://www.researchgate.net/figure/The-declination-of-the-sun_fig2_2349151.

${ }^{64}$ Dini Rahmadani, "Telaah Rumus Perhitungan Waktu Salat: Tinjauan Parameter Dan Algoritma," Al-Marshad: Jurnal Astronomi Islam Dan Ilmu-Ilmu Berkaitan 4 (2018): 177. 
The following table is declination data and maghrib time for one year in Pasuruan, East Java

\begin{tabular}{|c|c|c|}
\hline Date & Declination & Maghrib Time \\
\hline 1 January 2019 & $-23^{\circ} 0^{\prime} 8^{\prime \prime}$ & $17: 51$ \\
\hline 15 January 2019 & $-21^{\circ} 7^{\prime} 45^{\prime \prime}$ & $17: 56$ \\
\hline 28 January 2019 & $-18^{\circ} 12^{\prime} 28^{\prime \prime}$ & $17: 57$ \\
\hline 4 February 2019 & $-16^{\circ} 14^{\prime} 15^{\prime \prime}$ & $17: 57$ \\
\hline 14 February 2019 & $-13^{\circ} 2^{\prime} 4^{\prime \prime}$ & $17: 55$ \\
\hline 19 February 2019 & $-11^{\circ} 17^{\prime} 38^{\prime \prime}$ & $17: 54$ \\
\hline 27 February 2019 & $-8^{\circ} 21^{\prime} 42^{\prime \prime}$ & $17: 51$ \\
\hline 5 March 2019 & $-6^{\circ} 4^{\prime} 21^{\prime \prime}$ & $17: 49$ \\
\hline 12 March 2019 & $-3^{\circ} 20^{\prime} 23^{\prime \prime}$ & $17: 45$ \\
\hline 17 March 2019 & $-1^{\circ} 21^{\prime} 60^{\prime \prime}$ & $17: 43$ \\
\hline 26 March 2019 & $2^{\circ} 10^{\prime} 60^{\prime \prime}$ & $17: 39$ \\
\hline 31 March 2019 & $4^{\circ} 8^{\prime} 1^{\prime \prime}$ & $17: 36$ \\
\hline 8 April 2020 & $7^{\circ} 11^{\prime} 3^{\prime \prime}$ & $17: 32$ \\
\hline 16 April 2019 & $10^{\circ} 6^{\prime} 16^{\prime \prime}$ & $17: 29$ \\
\hline 22 April 2019 & $12^{\circ} 10^{\prime} 45^{\prime \prime}$ & $17: 26$ \\
\hline 28 April 2019 & $14^{\circ} 8^{\prime} 3^{\prime \prime}$ & $17: 24$ \\
\hline 8 May 2019 & $17^{\circ} 4^{\prime} 26^{\prime \prime}$ & $17: 21$ \\
\hline 16 May 2019 & $19^{\circ} 5^{\prime} 15^{\prime \prime}$ & $17: 20$ \\
\hline 1 June 2019 & $22^{\circ} 2^{\prime} 40^{\prime \prime}$ & $17: 20$ \\
\hline 10 June 2019 & $23^{\circ} 0^{\prime} 17^{\prime \prime}$ & $17: 20$ \\
\hline 18 July 2019 & $21^{\circ} 1^{\prime} 40^{\prime \prime}$ & $17: 29$ \\
\hline 27 July 2019 & $19^{\circ} 13^{\prime} 5^{\prime \prime}$ & $17: 30$ \\
\hline 4 August 2019 & $17^{\circ} 14^{\prime} 53^{\prime \prime}$ & $17: 31$ \\
\hline 15 August 2019 & $14^{\circ} 3^{\prime} 45^{\prime \prime}$ & $17: 31$ \\
\hline 24 August 2019 & $11^{\circ} 7^{\prime} 1^{\prime \prime}$ & $17: 31$ \\
\hline 30 August 2019 & $9^{\circ} 0^{\prime} 59^{\prime \prime}$ & $17: 30$ \\
\hline 7 September 2019 & $6^{\circ} 5^{\prime} 5^{\prime \prime}$ & $17: 29$ \\
\hline
\end{tabular}




\begin{tabular}{ccl}
\hline 12 September 2019 & $4^{\circ} 11^{\prime} 45^{\prime \prime}$ & $17: 28$ \\
\hline 20 September 2019 & $1^{\circ} 6^{\prime} 55^{\prime \prime}$ & $17: 27$ \\
\hline 26 September 2019 & $-1^{\circ} 13^{\prime} 9^{\prime \prime}$ & $17: 26$ \\
\hline 1 October 2019 & $-3^{\circ} 9^{\prime} 49^{\prime \prime}$ & $17: 25$ \\
\hline 9 October 2019 & $-6^{\circ} 14^{\prime} 23^{\prime \prime}$ & $17: 24$ \\
\hline 17 October 2019 & $-9^{\circ} 13^{\prime} 36^{\prime \prime}$ & $17: 24$ \\
\hline 22 October 2019 & $-11^{\circ} 1^{\prime} 32^{\prime \prime}$ & $17: 24$ \\
\hline 31 October 2019 & $-14^{\circ} 4^{\prime} 59^{\prime \prime}$ & $17: 25$ \\
\hline 7 November 2019 & $-16^{\circ} 15^{\prime} 19^{\prime \prime}$ & $17: 26$ \\
\hline 14 November 2019 & $-18^{\circ} 12^{\prime} 15^{\prime \prime}$ & $17: 34$ \\
\hline 28 November 2019 & $-21^{\circ} 17^{\prime} 18^{\prime \prime}$ & $17: 41$ \\
\hline 12 December 2019 & $-23^{\circ} 4^{\prime} 2^{\prime \prime}$ & 17 \\
\hline
\end{tabular}

Table 1. the Sun's Declination and Maghrib Praying Time

The above-mentioned the Sun's declination data is taken at 11 GMT in the Ephemeris Hisab Rukyat book of the Ministry of Religion of the Republic of Indonesia 2019. ${ }^{65}$ The calculation of the beginning of maghrib time utilize the ephemeris system by paying attention to the value of the height of the place, the low horizon, refraction, and semi-diameter of the Sun in order to get accurate results when the Sunset.

To explain the correlation between the Sun's declination and the beginning of the maghrib praying time, the data will be presented in the form of a diagram, then it will be analyzed its relationship.

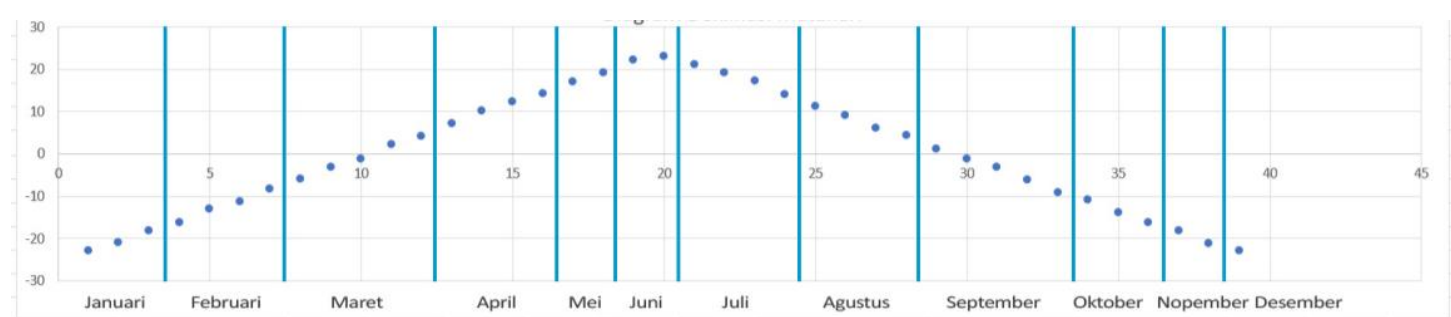

Image 7. The Diagram of Sun's Declination in 2019. 2019).

${ }^{65}$ Departemen Agama RI, Ephemeris Hisab Rukyat 2019 (Jakarta: Direktorat Urusan Agama Islam, 


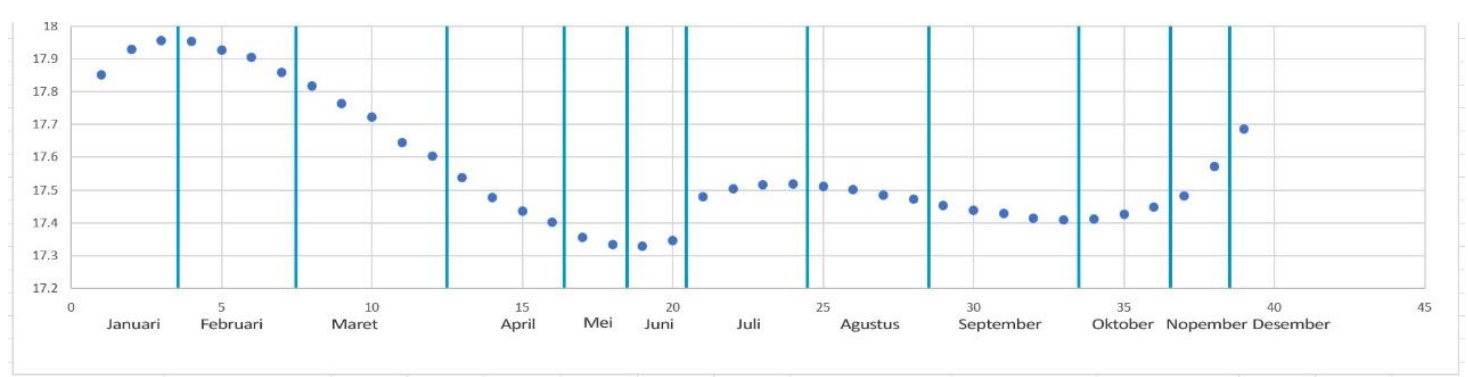

Image 8. The Diagram of the Beginning of Maghrib Praying Schedule.

The above two diagrams we can see that in January the sun's declination value increases by $5^{\circ}$ from 1 January 2019 with a declination value of $-23^{\circ} 0$ ' 8 "resulting in the beginning of maghrib time at 17: 51, then 28 January 2019 with a declination value of - $18^{\circ} 12$ '28 "results in the beginning of maghrib time at 17: 57 . From those results we can see that when the sun's declination value increases by $5^{\circ}$, the beginning of the maghrib time slows down by 6 minutes from 17:51 to $17: 57$.

The next data on the declination value and the beginning of the prayer time in February which also increased by $5^{\circ}$ from 4 February 2019 with a Sun's declination value of - $16^{\circ} 14$ '15 "resulting in the beginning of maghrib time at 17: 57, then the second data on 19 February 2019 with the Sun's declination value of - $11^{\circ} 17$ '38 ", this results in the beginning of the maghrib time at 17:54. From these results we know that when the Sun's declination value increases by $5^{\circ}$, the beginning of the maghrib time starts 3 minutes earlier than at 17:57 to $17: 54$.

In June, the Sun's declination reaches its highest value, then its value continues to decrease by $4^{\circ}$ from 10 June 2019 with a declination value of $23^{\circ} 0$ ' 17 "with the beginning of the maghrib time at 17: 20 to 27 July 2019 with a Sun's declination value of $19^{\circ} 13^{\prime} 5^{\prime \prime}$ produces the beginning of the maghrib time at 17:30. From these two data we can see that when the sun's declination value decreases, the beginning of the maghrib praying time slows down by 10 minutes from 17: 20 to 17: 30 .

Then the declination value decreases by $10^{\circ}$ from 24 August 2019 with a declination value of $11^{\circ} 7^{\prime} 1$ "resulting in the beginning of the maghrib praying time from 17: 30 to 20 September 2019 with a solar declination value of $1^{\circ} 6^{\prime} 55^{\prime \prime}$ resulting in the beginning of the maghrib prayer time at 17: $3017: 27$. From these two data, we can 
see that when the Sun's declination value decreases, the beginning of the maghrib prayer time is 3 minutes faster, from $17: 30$ to $17: 27$.

The above-mentioned analysist, we can see that there are several condition in the same event. First, when the sun's declination value increases, the beginning of the maghrib prayer time slows down. Second, when the sun's declination value increases, the beginning of the maghrib prayer time will be faster. Third, when the sun's declination value decreases, the beginning of the maghrib praying time slows down. Fourth, when the sun's declination value decreases, the beginning of the evening prayer time will be faster. From some of the conditions above, we can conclude that there is no correlation between the change in the value of the sun's declination and the beginning of the prayer time because when the sun's declination value increases or decreases, the beginning of the maghrib prayer time is also sometimes faster or slower. Therefore, to explain the cause of the change in the beginning of the maghrib praying time, we need another variable, in this context we will analyze the correlation with the analemma phenomenon.

C.5. The Correlation between Analemma and the Change of the Beginnig of Maghrib Praying Time.

Analemma is the inconstant motion of the Sun when it is observed in the same time and place within one year. The following is the data on the date of analemma image taking for one year by Muhammad Soleh, located in Pasuruan. 15 July 2019, 1 August 2019, 16 August 2019, 1 September 19, 8 September 19, 15 September 19, 1 October 2019, 1 November 2019, 15 November 2019, 1 December 2019, 15 December 2019, 1 January 2020, 15 January 2020, 31 January 2020, 16 February 2020, 1 March 2020, 16 March 2020, 31 March 2020, 15 April 2020, 20 April 2020, 1 May 2020, 15 May 2020, 1 June 2020, 16 June 2020, and 1 July 2020. 


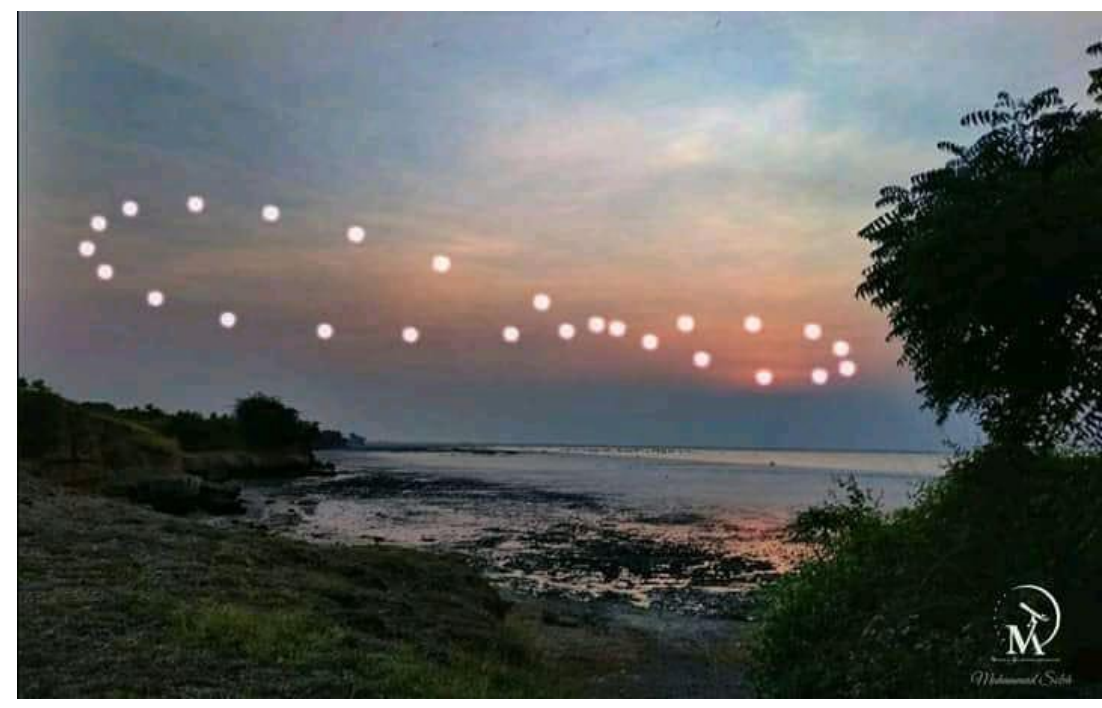

Image 9. The Photographic image of Analemma by Muhammad Sholeh.

To find out the correlation between the analemma phenomenon and the insconstant of the beginning maghrib praying time, the following table is presented which contains the date of taking the analemma image, the difference between the shooting time as well as the beginning of the maghrib praying time, and the beginning of the maghrib praying time.

\begin{tabular}{|c|c|c|}
\hline Shooting Date & Shooting time -Maghrib Time & Maghrib Time \\
\hline 15 July 2019 & Oj $43 \mathrm{~m}$ & $17: 28$ \\
\hline 1 August 2019 & $0 \mathrm{j} 45 \mathrm{~m}$ & $17: 30$ \\
\hline 16 August 2019 & Oj 46m & $17: 31$ \\
\hline 1 September 2019 & $0 \mathrm{j} 44 \mathrm{~m}$ & $17: 29$ \\
\hline 8 September 2019 & $0 \mathrm{j} 43 \mathrm{~m}$ & $17: 28$ \\
\hline 15 September 2019 & $0 \mathrm{j} 42 \mathrm{~m}$ & $17: 27$ \\
\hline 1 October 2019 & $0 \mathrm{j} 40 \mathrm{~m}$ & $17: 25$ \\
\hline 1 November 2019 & $0 \mathrm{j} 40 \mathrm{~m}$ & $17: 25$ \\
\hline 15 Nopember 2019 & $0 \mathrm{j} 44 \mathrm{~m}$ & $17: 29$ \\
\hline 1 December 2019 & 0j $50 \mathrm{~m}$ & $17: 35$ \\
\hline 15 December 2019 & Oj $57 \mathrm{~m}$ & $17: 42$ \\
\hline 1 January 2020 & $1 \mathrm{j} 5 \mathrm{~m}$ & $17: 50$ \\
\hline 15 January 2020 & $1 \mathrm{j} 10 \mathrm{~m}$ & $17: 55$ \\
\hline
\end{tabular}




\begin{tabular}{|c|c|c|}
\hline 31 January 2020 & $1 \mathrm{j} 12 \mathrm{~m}$ & $17: 57$ \\
\hline 16 February 2020 & $1 \mathrm{j} 10 \mathrm{~m}$ & $17: 55$ \\
\hline 1 Mach 2020 & $1 \mathrm{j} 5 \mathrm{~m}$ & $17: 50$ \\
\hline 16 March 2020 & Oj $58 \mathrm{~m}$ & $17: 43$ \\
\hline 31 March 2020 & Oj $50 \mathrm{~m}$ & $17: 35$ \\
\hline 15 April 2020 & $0 \mathrm{j} 43 \mathrm{~m}$ & $17: 28$ \\
\hline 20 April 2020 & $0 \mathrm{j} 41 \mathrm{~m}$ & $17: 26$ \\
\hline 1 May 2020 & $0 \mathrm{j} 37 \mathrm{~m}$ & $17: 22$ \\
\hline 15 May 2020 & $0 \mathrm{j} 35 \mathrm{~m}$ & $17: 20$ \\
\hline 1 June 2020 & $0 \mathrm{j} 34 \mathrm{~m}$ & $17: 19$ \\
\hline 16 June 2020 & $0 \mathrm{j} 36 \mathrm{~m}$ & $17: 21$ \\
\hline 1 July 2020 & $0 \mathrm{j} 40 \mathrm{~m}$ & $17: 25$ \\
\hline
\end{tabular}

Tabel 2. The date of the analemma image taking, the difference between the shooting time and the beginning of the maghrib prayer time, and the beginning of the maghrib prayer time. ${ }^{66}$

Analemma image was taken every two weeks for one year at 16.45 WIB in the same place. Whereas if there is a one-day shift due to the weather on the specified date it does not support image capture. To find out whether there is a correlation between the analemma phenomenon and the change in the beginning of the maghrib prayer time, the authors use two variables, namely the difference between the time to shoot the image and the beginning of the maghrib prayer time based on the ephemeris calculation system. The two data will form the same position as the analemma image, as follows:

${ }^{66}$ The data for calculate begining of maghrib prayer was taken from Ephemeris book year 2019 2020. RI; Departemen Agama RI, Ephemeris Hisab Rukyat 2020 (Jakarta: Direktorat Urusan Agama Islam, 2020). 


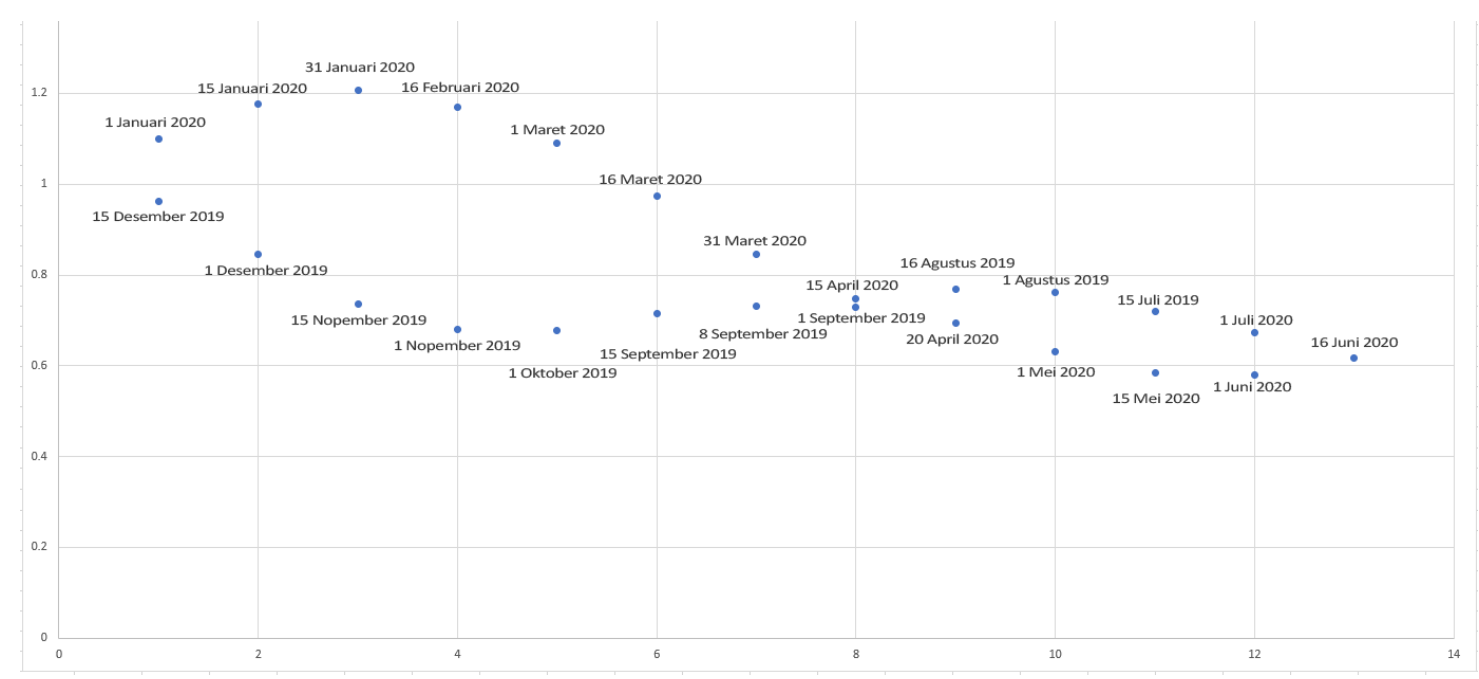

Image 10. The diagram of the beginning maghrib time based on the date of analemma image shooting

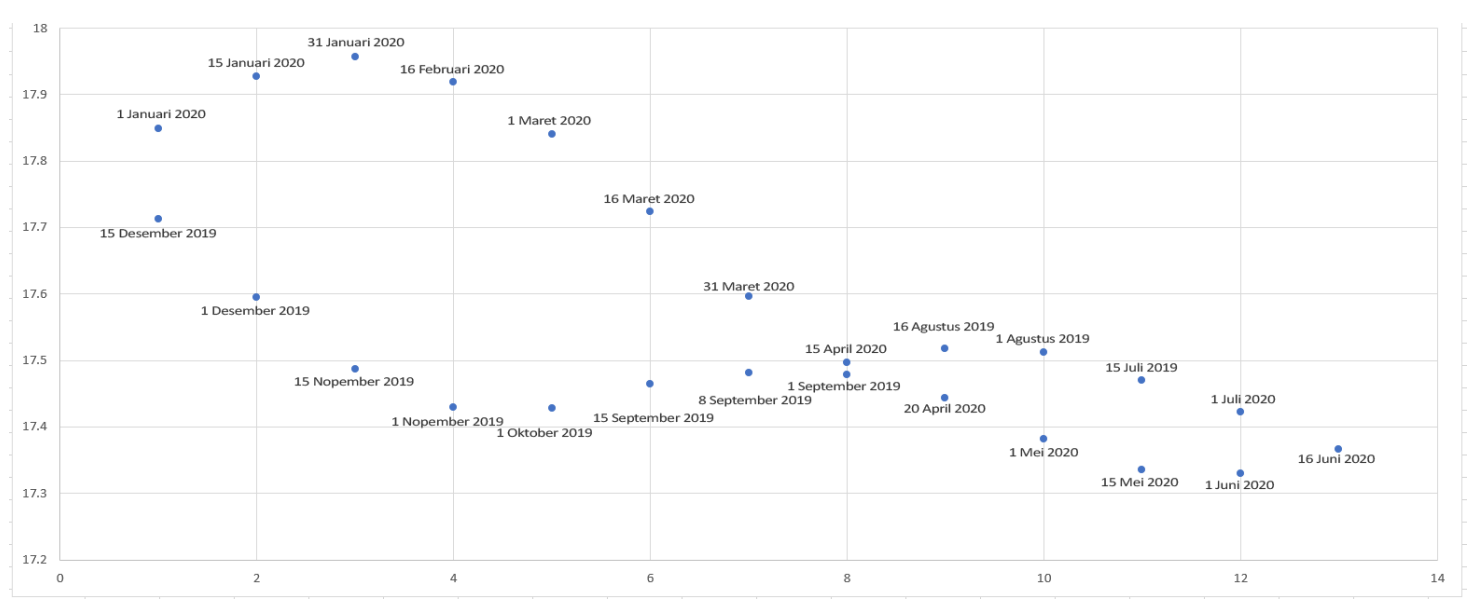

Image 11. The diagram of the difference between the shooting time and the beginning of the maghrib praying time

We can read the diagram from the top small circle point that shows the date of 15 July 2019, which is the beginning of data collection, then move to the left through the bottom large circle, then rotate to the upper large circle then go to the lower small circle. The order of data arrangement on the diagram is adjusted to the shooting date of the analemma image.

From the two diagram above, we can see that there is a correlation between the analemma phenomenon and the beginning of the maghrib prayimg time. Meanwhile, the value of the difference between shooting and maghrib time has changed from 15 July 2019 to 1 August 2019, which has increased from $0^{\mathrm{h}} 43^{\mathrm{m}}$ to $0^{\mathrm{h}} 45^{\mathrm{m}}$. Then the 
diagram of the maghrib praying time on 15 July 2019 to 1 August 2020 is getting slower, starting at 17: 28 to $17: 30$. The two variables shows that when the value of the difference between shooting increased, the value of the maghrib time slows down.

The subsequent data from 8 September 2019 to 1 October 2019, the value of the difference between shooting time and maghrib time has decreased from $0^{\mathrm{h}} 43^{\mathrm{m}}$ to $0^{\mathrm{h}}$ $40^{\mathrm{m}}$. At the same time, maghrib time accelerated on that date, starting at 17:28 to 17 : 25 on October 1, 2019. The two changes of these variables, it can be seen that when the value of the difference shooting time decreases, the value of the maghrib time accelerates.

In December to January, the difference value of shooting time has increased, starting at $0^{\mathrm{h}} 57^{\mathrm{m}}$ on 15 December 2019 to $1^{\mathrm{h}} 12^{\mathrm{m}}$. on 31 January 2020. Then, the diagram of the beginning of the maghrib praying time on December 15, 2019, is 17:42 then on January 31, 2020 it becomes 17: 57, the beginning of the maghrib time slows down by about 22 minutes. From these two variables, it can be seen that when the shooting difference value increases, the beginning of the maghrib prayer time slows down.

Then on April 20, 2020 to May 15, 2020, the difference value of the shoot decreased by about 6 minutes from $0^{\mathrm{h}} 41^{\mathrm{m}}$ to $0^{\mathrm{h}} 35^{\mathrm{m}}$. On the same date, which is April 20, 2020, the beginning of maghrib time is at 17:26 then on May 15, 2020 it becomes 17:20, getting 6 minutes faster. From these two variables, it can be seen that when the difference value of the shoot decreases, the beginning of the maghrib time will be faster.

\section{Conclusion}

The cause of the inconstant of the beginning of the maghrib praying time was initially due to a change in the value of the sun's declination. However, the research found that the declination value was not correlated with the change in the initial time of the Maghrib prayer. When the sun's declination value increases, sometimes the beginning of the maghrib praying time gets faster and slower. When the sun's declination value decreases, sometimes the beginning of the maghrib praying time gets faster and sometimes slower. It is because there is no correlation was found between 
changes in the value of the declination of the sun and the beginning of praying time. Therefore, another variable was needed, namely the analemma phenomenon.

The position of the sun observed in the same time and place for one year is not stationary in its position, but fluctuates and forms like a figure eight which is called the analemma phenomenon. The phenomenon cause the height of the sun changes at the same time, then it affects the value of the time difference between analemma shooting and the beginning of the maghrib time to change. When the difference in shooting time is reduced, the beginning of the maghrib time is getting faster and when the difference in shooting time is increased, the beginning of the maghrib time is getting slower.

\section{E. References}

Abi Thalhah, Ali bin. "Tafsir Ibnu Abbas." Jakarta: Pustaka Azzam, 2009.

Al-Juzairi, Syaikh Abdurrahman. Fikih Empat Madzhab Jilid 1. Vol. 1. Jakarta: Pustaka AlKautsar, 2015.

An-Nawawi. Al-Majmu' Syarah Al-Muhadzdzab Jilid 3. Jakarta: Pustaka Azzam, 2015.

Aslaksen, Helmer. "The Analemma for Latitudinally-Challenged People The Analemma for Latitudinally-Challenged People Department of Mathematics,” no. January 2001 (2014).

Aviv, Zulfia. "Studi Analisis Ihtiyath 10 Menit Sebelum Subuh Untuk Waktu Imsak Dalam Sistem Informasi Hisab Rukyat (Sihat) Indonesia.” Universitas Islam Negeri Walisongo Semarang, 2017.

Azhari, Susiknan. Ensiklopedi Hisab Rukyat. Yogyakarta: Pustaka Pelajar, 2012.

Blateyron, François. “The Analemmatic Sundial.” Accessed November 11, 2020. https://www.shadowspro.com/en/analemmatic-sundial.html.

Budd, C.J. "The Declination of The Sun." Accessed November 26, 2020. http://www.researchgate.net/figure/The-declination-of-the-sun_fig2_2349151.

Butar-Butar, Arwin Juli Rakhmadi. "Pengantar Ilmu Falak.” Cet. I, Yogyakarta: Rajawali Pers, 2018.

Cicco, Dennis di. "The First Ever Analemma." Accessed November 11, 2020. http://twanight.org/newTWAN/photos.asp?ID=3001422. 
Firdaus, Thoha, And Arini Rosa Sinensis. "Perdebatan Paradigma Teori Revolusi: Matahari Atau Bumi Sebagai Pusat Tata Surya?” Titian Ilmu: Jurnal Ilmiah Multi Sciences 9 (2017). Gangui, Alejandro, Cecilia Lastra, and Fernando Karaseur. "On Times and Shadows: The Observational Analemma." The Physics Teacher, 2018.

Ghazi, Muhammad Bin Qasim Al. Fathul Qarib AL-Mujib. Semarang: Toha Putra, 2010.

Hambali, Slamet. "Ilmu Falak I (Penentuan Awal Waktu Salat Dan Arah Kiblat Dunia)." Semarang: Program Pasca Sarjana IAIN Walisongo Semarang, 2011.

—. "Menguji Kakuratan Hasil Pengukuran Arah Kiblat Menggunakan Istiwaaini Karya Slamet Hambali,” 2014.

—_. "Pengantar Ilmu Falak, Menyimak Proses Pembentukan Alam Semesta.” Banyuwangi: Bismillah Publisher, 2012.

Hidayat, Muhammad. "Penyebab Perbedaan Hasil Perhitungan Jadwal Waktu Salat Di Sumatera Utara.” Al-Marshad: Jurnal Astronomi Islam Dan Ilmu-Ilmu Berkaitan, 2018.

HORIZONZ, The. "Analemma for Planet Earth." Accessed November 11, 2020. https://commons.wikimedia.org/wiki/File:Analemma_Earth.png.

Ismail. "Metode Penentuan Awal Waktu Salat Dalam Perspektif Ilmu Falak." Jurnal Ilmiah Islam Futura, 2015.

Izzuddin, Ahmad. Ilmu Falak Praktis: Metode Hisab-Rukyat: Praktis Dan Solusi Permasalahannya. Pustaka Rizki Putra, 2012.

Jamil, A. Ilmu Falak Teori E⿱ Aplikasi (Arah Kiblat, Awal Waktu, Dan Awal Tahun). Jakarta: Amzah, 2018.

Kemenag, R I. “Al-Qur'an Dan Terjemahnya.” Jakarta: PT Sinergi Pustaka Indonesia, 2012.

Kerrod, Robbin. "Bengkel Ilmu Astronomi, Terj." Syamaun Peusangan, Jakarta: Penerbit Erlangga, 2005.

Khazin, Muhyiddin. Ilmu Falak Dalam Teori Dan Praktik. Yogyakarta: Buana Pustaka, 2005.

—. Kamus Ilmu Falak. Yogyakarta: Buana Pustaka, 2005.

Ma'u, Dahliah, Haliah. "Waktu Sholat Pemaknaan Syar' I Ke Dalam Kaidah Astronomi." Jurnal Hukum Islam 14, no. 2 (2015): 269-85.

Matzner, Richard A. Dictionary of Geophysics, Astrophysics, and Astronomy. CRC Press, 2018. Muhajir. “Awal Waktu Shalat Telaah Fiqh Dan Sains.” Madinah: Jurnal Studi Islam 6 (2019). 
Mumtahana, F., Sartika, A. G. Admiranto, E. Sungging, M. Z. Nurzaman, R. Priyatikanto, and T. Dani. "Tutulemma of near Equator Partial Solar Eclipse 2016." Journal of Physics: Conference Series 771, no. 1 (2016).

Nabil. "Pendidikan Ilmu Astronomi Dari Historis Sampai Heliosentris.” Al Marhalah : Jurnal Pendidikan Islam 2 (2018).

Rahmadani, Dini. "Telaah Rumus Perhitungan Waktu Salat: Tinjauan Parameter Dan Algoritma.” Al-Marshad: Jurnal Astronomi Islam Dan Ilmu-Ilmu Berkaitan 4 (2018).

RI, Departemen Agama. Ephemeris Hisab Rukyat 2019. Jakarta: Direktorat Urusan Agama Islam, 2019.

—. Ephemeris Hisab Rukyat 2020. Jakarta: Direktorat Urusan Agama Islam, 2020.

—. Ephemeris Hisab Rukyat 2021. Jakarta: Direktorat Urusan Agama Islam, 2021.

RI, Kemenag. Ilmu Falak Praktik. Jakarta Pusat: Sub Direktorat Pembinaan Syariah Dan Hisab Rukyat, 2013.

Rojak, Encep Abdul, Amrullah Hayatudin, and Muhammad Yunus. "Koreksi Ketinggian Tempat Terhadap Fikih Waktu Salat: Analisis Jadwal Waktu Sholat Kota Bandung.” AlAhkam, 2017.

Sabda, Abu. Ilmu Falak Rumusan Syar'i Dan Astronomi Seri 01 : Waktu Shalat Dan Arah Kiblat. Bandung: Persis Pers, 2020.

Shivalingaswamy, T, and B A Kagali. "Determination of the Declination of the Sun on a Given Day" 3, no. 1 (2012): 17-22.

Sidoli, Nathan. "Mathematical Methods in Ptolemy's Analemma." In Ptolemy's Science of the Stars in the Middle Ages, 35-77. Brepols Publishers, 2020.

Syafi'i, Asy. Al Umm Jilid 2 Terj. Misbah. Jakarta: Pustaka Azzam, 2014.

Ulum, Fathul. "Studi Komparatif Hisab Penentuan Awal Waktu Shalat Dalam Kitab AlDurusul Al-Falakiyah Dan Ephemeris.” Institut Agama Islam Negeri Ponorogo, 2020. 